\title{
The U.S.- Japan- China Trilateral Cooperation toward a New Climate Regime
}

\author{
Fengjun Duan $^{1,2, *}$, Takahisa Yokoyama ${ }^{1}$, Tetsuo Yuhara ${ }^{1}$ \\ ${ }^{1}$ The Canon Institute for Global Studies, Japan \\ ${ }^{2}$ Faculty of Engineering, The University of Tokyo, Japan
}

Copyright (C) 2015 by authors, all rights reserved. Authors agree that this article remains permanently open access under the terms of the Creative Commons Attribution License 4.0 International License

\begin{abstract}
This paper examines the possibility of establishing a trilateral cooperation scheme between U.S., Japan and China, based on a global energy vision against climate change. Through global energy model projection and data analysis, a mutually dependent and mutually complementary relationship has been confirmed between the three countries. Trilateral cooperation will not only contribute to overcoming the current environment danger but also contribute to energy security and maintaining industrial competitiveness and make international contributions. Cooperation schemes should be established that go beyond the limits of existing bilateral cooperation with regard to strategy, implementation and deployment. Based on intergovernmental agreements, infrastructure for the full process flow of technology development, demonstration, industrialization and deployment should be built as the base for cooperation.
\end{abstract}

Keywords Climate Regime, U.S., Japan, China, Trilateral Cooperation, Technology Deployment

\section{Introduction}

The international cooperation efforts are located in the central position for achieving global vision against climate change. However, the fruitless negotiations during the recent COPs illustrate the difficulty of reaching a legally binding international agreement. Therefore, quickly actions taken under regional or multilateral scheme are essential if we won't like to lose too many times and get started too late. The EU ETS is still going ahead even through it is facing many difficulties, and Japanese Government developed a bilateral offset credit mechanism and concluded 8 agreements with developing countries. But all of these parties only cover no more than $20 \%$ of the global emissions; thereby the actions cannot solve the problem essentially.

China became the largest $\mathrm{CO}_{2}$ emitter ten years after the adoption of the Kyoto Protocol. In addition, with the predicted rapid economic growth, China's energy demands will increase substantially during the following decades. United States, the second biggest emitter, has the highest energy consumption per capita. Therefore, the decarbonizing energy systems in the two countries that cover more than $40 \%$ of the global emissions will play the most essential role on combating climate change. On the other hand, limited by the national energy conditions, Japan developed most of the climate technologies those are the key to solve the climate problem. Therefore, this paper examines the possibility to establish a trilateral cooperation scheme based on a global energy vision against climate change.

\section{Global Vision and National Missions}

A global vision against climate change was examined based on climate science, energy model and economic assessment $[1,2]$. It proposed a new emission pathway based on zero-emission and overshoot schemes, named Z650 instead of the traditional 450ppm equilibrium stabilizaiton of IPCC. The essential limitation is that the total emission during the $21^{\text {st }}$ century should be lower than $650 \mathrm{GtC}$. The scientific examinations demonstrated that the Z650 scenario could avoid long-term risks while meeting short term need of relatively large emissions [3].

A globally optimal way to realize the Z650 scenario was analyzed through the numerical projections using a global energy model so called GRAPE (Global Relationship Assessment to Protect the Environment) model [4]. Fifteen regions were set in the model to cover the global aggregate, those are: United States, Western Europe, Japan, Canada, Oceania, Russia, Central Europe, East Europe, China, India, ASEAN countries, Middle East and Northern Africa, Southern Africa, Brazil, and Latin America. The final energy demands for every region were assumed based on population and economic growth, while the technology assumptions were examined based on previous researches [5-21]. The cost minimization of global energy system was carried out to optimize the global and regional energy supply. 
A BAU (Business as Usual) scenario that assumed no changes of the current energy and environmental policies in the future was analyzed together with the Z650 scenario that assumed a global $\mathrm{CO}_{2}$ emission cap described above. The necessary $\mathrm{CO}_{2}$ reductions by five sectors to achieve $\mathrm{Z} 650$ limitation from BAU scenario were examined based on the projection results. The energy conservation sector reflects the reductions in demand side, while the other four sectors in supply side. The main measurement in energy conservation sector is efficiency improvement. The measurements in power generation, transportation and stationary energy supply for residential and industry include efficiency improvement and fuel shift. The CCS (Carbon Capture and Storage) was analyzed as an independent sector because it will play a large role in the whole picture. Figures 1-3 illustrate the projected necessary domestic efforts for U.S., Japan and China under idealized conditions from 2010 to 2050 respectively. At meanwhile, Table 1 summarizes some key index for the three countries such as emission intensity, primary energy mix, power generation mix, and so on, to realize the $\mathrm{Z} 650$ scenario.

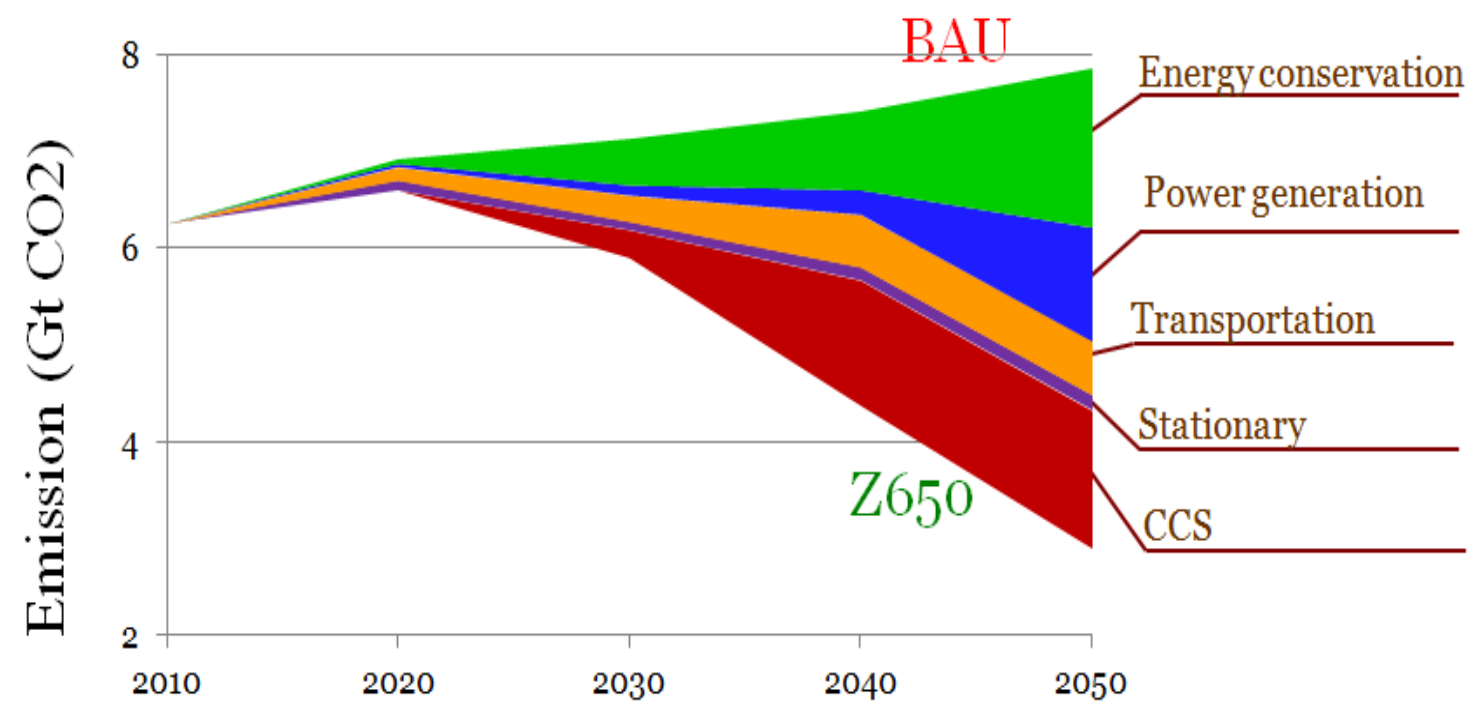

Figure 1. Necessary reduction efforts by sectors in U.S.

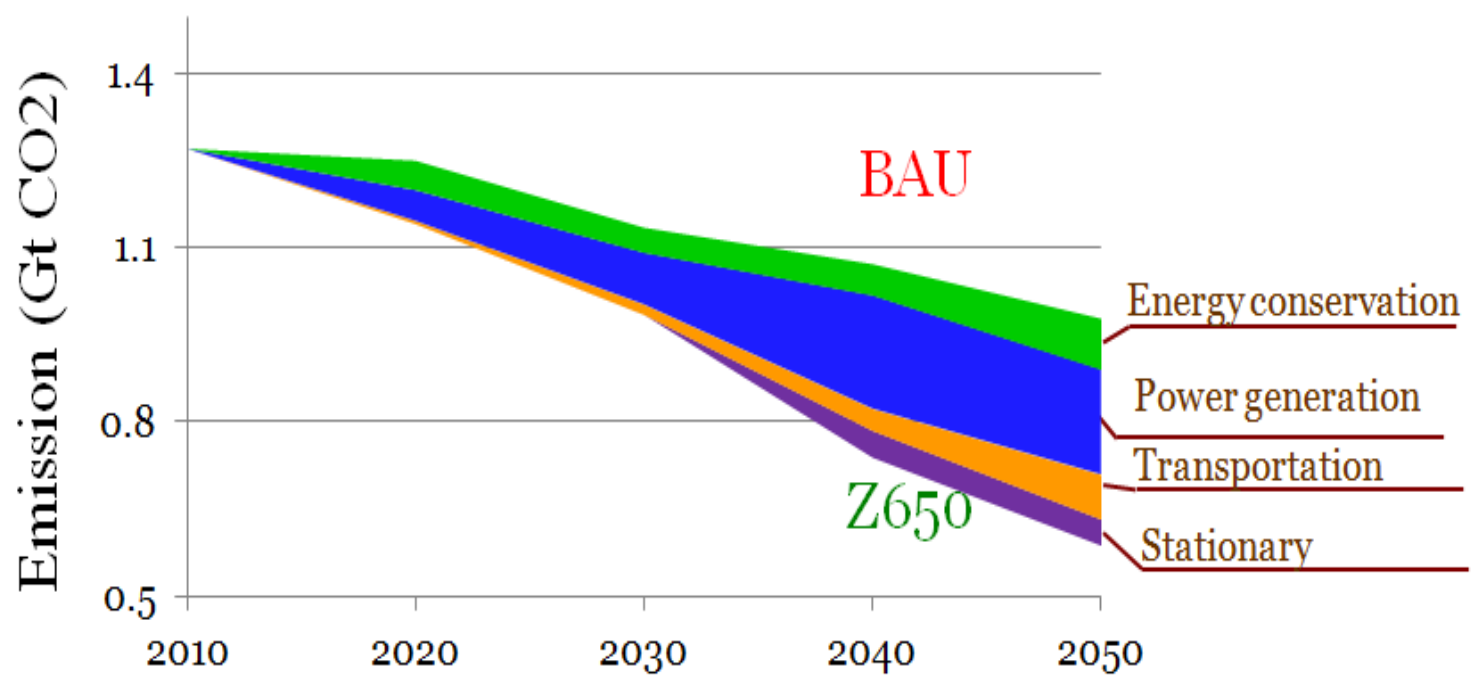

Figure 2. Necessary reduction efforts by sectors in Japan 


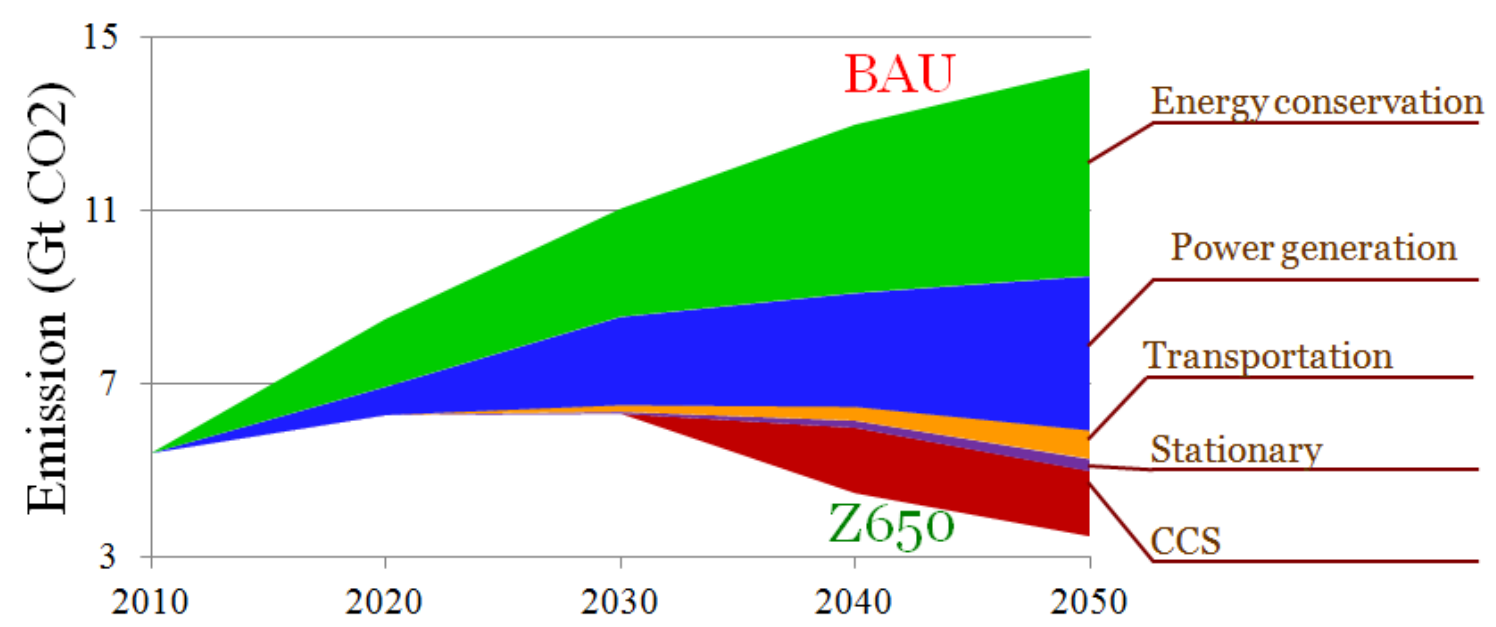

Figure 3. Necessary reduction efforts by sectors in China

Table 1. Necessary domestic effort of U.S., Japan and China for achieving the global vision

\begin{tabular}{|c|c|c|c|c|c|c|}
\hline \multirow{2}{*}{ Target } & \multicolumn{2}{|c|}{ United States } & \multicolumn{2}{|c|}{ Japan } & \multicolumn{2}{|c|}{ China } \\
\hline & 2030 & 2050 & 2030 & 2050 & 2030 & 2050 \\
\hline $\begin{array}{c}\mathrm{CO}_{2} \text { Emission } \\
\text { (Ratio to } 2005 \text { levels) }\end{array}$ & 0.96 & 0.47 & 0.79 & 0.47 & 1.48 & 0.82 \\
\hline $\begin{array}{l}\text { Emission Intensity } \\
\left(\mathrm{tCO}_{2} / \mathrm{GDP}\right)\end{array}$ & 0.28 & 0.09 & 0.12 & 0.06 & 0.40 & 0.12 \\
\hline $\begin{array}{l}\text { Energy Intensity } \\
\text { (TOE/GDP) }\end{array}$ & 0.12 & 0.09 & 0.05 & 0.04 & 0.20 & 0.13 \\
\hline $\begin{array}{l}\text { Energy Mix } \\
\text { (FF: NE: RE) }\end{array}$ & $8: 1: 1$ & $5: 2: 3$ & $7: 2: 1$ & $6: 2: 2$ & $6: 2: 2$ & $4: 3: 3$ \\
\hline $\begin{array}{l}\text { Power Generation } \\
\text { (FF: NE: RE) }\end{array}$ & $7: 2: 1$ & $3: 4: 3$ & $4: 4: 2$ & $3: 4: 3$ & $4: 3: 3$ & $2: 4: 4$ \\
\hline Portfolio & \multicolumn{2}{|c|}{$\begin{array}{c}\text { Energy Saving } \\
\text { Energy Conversion } \\
\text { CCS }\end{array}$} & \multicolumn{2}{|c|}{$\begin{array}{l}\text { Energy Saving } \\
\text { Energy Conversion }\end{array}$} & \multicolumn{2}{|c|}{$\begin{array}{c}\text { Energy Saving } \\
\text { Energy Conversion } \\
\text { CCS }\end{array}$} \\
\hline
\end{tabular}

The model projection results show that United States needs to pay more attention to energy saving and transportation sector in 2030, and in 2050 the measurements in power sector will be the most important especially the application of CCS in order to reduce their emissions by $4 \%$ and 53\% compared with the 2005 level in 2030 and 2050 respectively (Fig. 1). Energy intensity should be improved by $25 \%$, and large scale utilization of renewable energy should be introduced in the place of fossil fuel (Table 1).

In Japan, because of the current high energy efficiency, introduction of clean energy in power sector will be constantly essential in order to reduce their emissions by $21 \%$ and $53 \%$ compared with the 2005 level in 2030 and 2050 respectively (Fig. 2). Limited by the national energy conditions, the adjustment of energy mix will be not easy, but the nuclear and renewable energy should contribute more in the future (Table 1).

As for China, energy saving and power sector will be equally important duing the whole period even though the national emissions could be $48 \%$ more than the 2005 level in 2030 before a reduction of 18\% in 2050 (Fig. 3). Energy intensity should improved by $35 \%$, and clean energy should contribute more than half of the total energy supply in 2050 (Table 1).

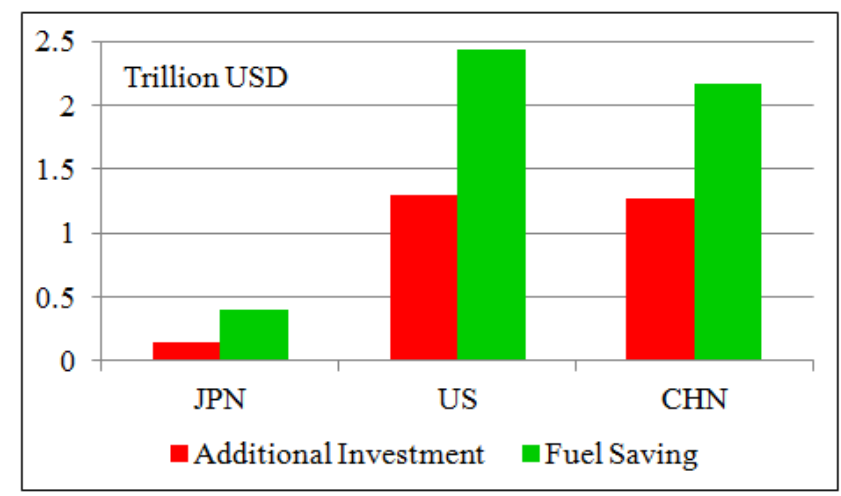

Figure 4. the cost-benefit analysis during 2010-50 
An cost-benefit analysis of the energy system indicated that the additional investments of United States, Japan and China will ocuppy $0.14 \%, 0.05 \%$ and $0.20 \%$ of their GDP duing the follwing 40 years respctively, but the fuel saving could cover them in each country (Fig. 4).

\section{Factors for Cooperation}

Generally, there are some essential factors for combating climate change. Resources potential, technology capacity, production capability, and economic capacity are four of them. The comparison between the three countries on these four factors are summarized in Table 2. For the resource potential, Japan has almost no domestic resources except renewable; China has coal, but need to import oil and natural gas; benefited by the shale revolution, U.S. is able to become in energy independent by the end of 2015 . For the technology capacity, Japan developed $37.1 \%$ of the global climate technologies during 2000-2005 (Fig. 5); the shares of U.S. and China are $11.8 \%$ and $8.1 \%$ respectively. For the production capacity, China produced about half of the global PV cells and near $30 \%$ of global wind turbine in 2011; while U.S. produced near $10 \%$ of global wind turbine and Japan produced near $10 \%$ of global PV cells. Finally, for the economic capacity, the three countries are the top three economic bodies in the world.

A mutually dependent and mutually complementary relationship between the three countries can be confirmed. United States has high capacity of energy resources which could benefit the energy security of China and Japan; Japan has high capacity of climate technology which could help the decarbonization process in United States and China; China has high capacity of equipment production which are necessary for the green energy introduction in United States and Japan. In addition, the three countries have the economic capacity to invest the migitations.

Table 2. Comparison between U.S., Japan and China related to combating climate change

\begin{tabular}{|c|c|c|c|}
\hline & China & Japan & United States \\
\hline $\begin{array}{c}\text { Resources } \\
\text { Potential }\end{array}$ & $\triangle$ & $\times$ & $\bigcirc$ \\
\hline $\begin{array}{c}\text { Technology } \\
\text { Capacity }\end{array}$ & $\times$ & $\bigcirc$ & $\triangle$ \\
\hline $\begin{array}{c}\text { Production } \\
\text { Capacity }\end{array}$ & $\bigcirc$ & $\times$ & $\triangle$ \\
\hline $\begin{array}{c}\text { Economic } \\
\text { Capacity }\end{array}$ & $\bigcirc$ \\
\hline
\end{tabular}

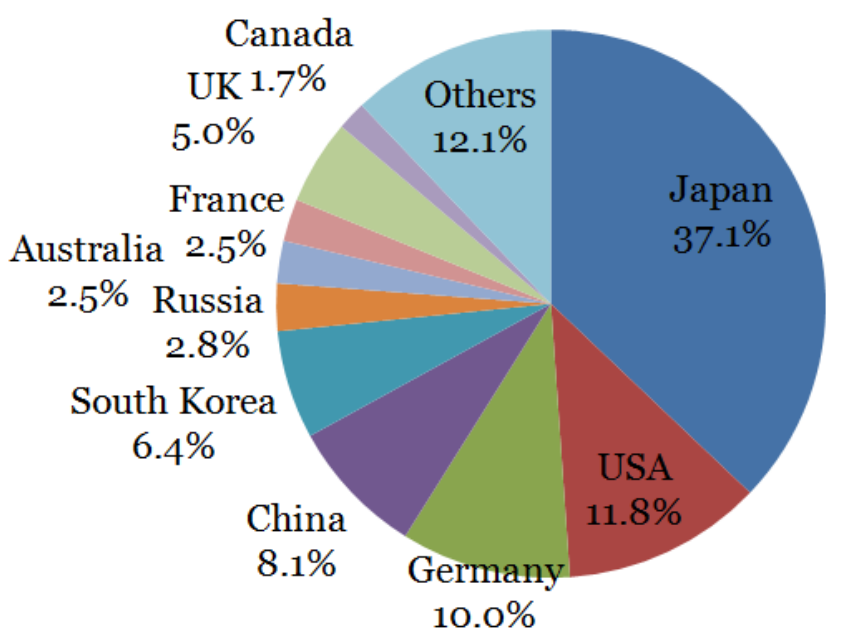

Figure 5. Global Climate Technology Innovations (2000-05) (Based on A. Dechezlepretre et al. [22])

\section{Current Bilateral Cooperation and Proposal}

The current bilateral collaboration and cooperation between the three countries are summarized in Table 3. All of the three bilateral cooperation on energy and environmental issues have been promoted for some decades. However, most of the Uinted States-Japan cooperations are innovation oriented, thereby advanced technologis can be developed, but deployment tend to be limited; most of the United States-China cooperations are policy oriented, thereby strategic plans and agreements were concluded, but practical improvement is not enough; most of the Japan-China cooperations are business oriented, thereby losts of projects were performed, but a tatal framework is not in the place.

Table 3. Current bilateral cooperations of the three countries

\begin{tabular}{|l|c|c|c|}
\hline Approach & $\begin{array}{c}\text { China-Japan } \\
\text { Governmental dialogue } \\
\text { Private sector }\end{array}$ & $\begin{array}{c}\text { Governmental dialogue } \\
\text { Thinktank }\end{array}$ & $\begin{array}{c}\text { Governmental dialogue } \\
\text { Institution }\end{array}$ \\
\hline Contents & $\begin{array}{c}\text { Technology cooperation } \\
\text { Project }\end{array}$ & $\begin{array}{c}\text { Strategy } \\
\text { Policy }\end{array}$ & R\&D \\
\hline Characteristic & Business oriented & Policy oriented & Innovation oriented \\
\hline Limitation & Strategic scope & Workability & Deployment \\
\hline
\end{tabular}


In order to address the limitations of the bilateral cooperation mentioned above, we propose a trilateral cooperation scheme illustrated in Figure 6. First step would be trilateral agreement between the governments of United States, Japan, and China. Based on the agreement, the common standard, regulation and IPR will be created. Following the common criteria, the collaborated R\&D center, equipment manufactory and project implementation center will be set up to develop technology, produce equipment and develop business model. This scheme could contribute to not only the internal application, but also external applications such as technology deployment to developing countries.

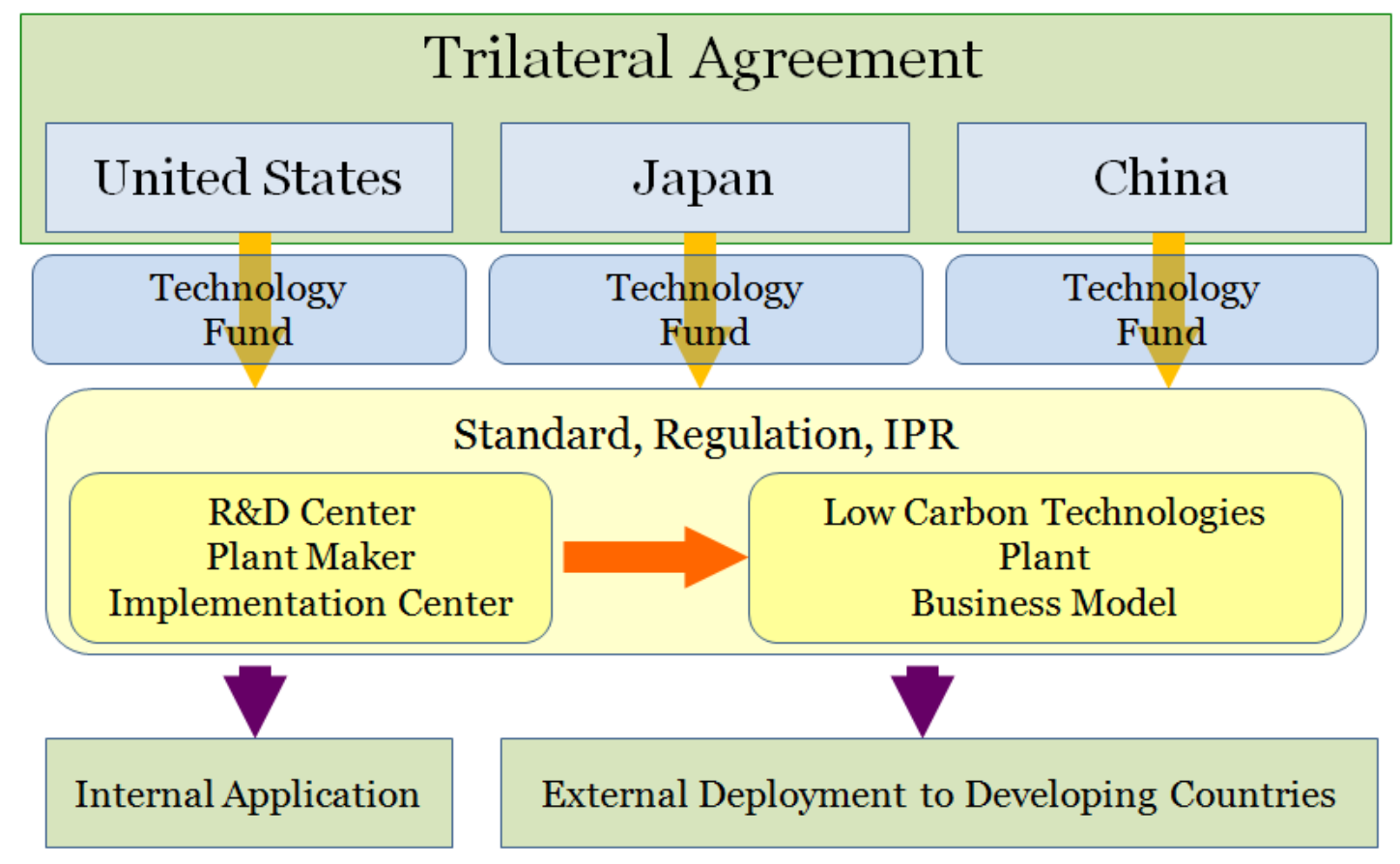

Figure 6. The image of the trilateral cooperation scheme

The contents and targets of the trilateral cooperation can be divided into four areas (Table 4), the energy production, the energy conversion, energy consumption, and finally establishment of green lifestyle.

Table 4. Contents and expected outputs of the trilateral cooperation

\begin{tabular}{|l|c|c|c|}
\hline \multirow{2}{*}{ Green Energy Production } & China & Japan & United States \\
\cline { 2 - 4 } & Coal, RE & RE & Coal, Oil, Gas \\
\cline { 2 - 4 } & \multicolumn{3}{|c|}{ Best Energy Mix } \\
\hline $\begin{array}{l}\text { Guclear, RE, } \\
\text { CCS } \\
\text { Energy Conversion }\end{array}$ & Fossil, Nuclear & $\begin{array}{c}\text { Nuclear, RE, } \\
\text { CCS }\end{array}$ \\
\cline { 2 - 4 } & \multicolumn{3}{|c|}{ Zero Emission Power Generation } \\
\hline \multirow{2}{*}{$\begin{array}{l}\text { Improvement of Energy } \\
\text { Consumption }\end{array}$} & Transportation & $\begin{array}{c}\text { Industry, } \\
\text { Residential }\end{array}$ & Residential \\
\cline { 2 - 4 } & \multicolumn{3}{|c|}{ High Energy Efficiency } \\
\hline $\begin{array}{l}\text { Establishment of Green Life } \\
\text { Style }\end{array}$ & $\begin{array}{c}\text { Reverse } \\
\text { Innovation }\end{array}$ & $\begin{array}{c}\text { Advanced } \\
\text { Technology }\end{array}$ & $\begin{array}{c}\text { Advanced } \\
\text { Social System }\end{array}$ \\
\cline { 2 - 4 } & Industrialization Model for Developing Countries \\
\hline
\end{tabular}


In the energy production area, China would focus on the clean use of coal and promotion of renewable energy; Japan would focus on renewable energy; and U.S. would focus on clean use of all the fossil fuels. The target of this area is to construct national best energy mix. In the energy conversion area, all of the three countries would keep the promotion of nuclear and renewable energy; while U.S. and China would also pay attention to CCS. The target of this area is the zero emission power generation. In the energy consumption area, China should pay more attention to transportation; U.S. and Japan should promote efficiency in residential sector. The target of this area is the high efficiency.

As to lifestyle, U.S. could contribute by their advanced social system; Japan could contribute by the advanced technology; China could contribute by the capacity of reverse innovation. The target is to develop suitable industrialization model for developing countries.

\section{Expected Cooperation Effects}

Through the proposed trilateral cooperation, large scale effects in combating global warming can be expected both internal (within the three countries) and external (global contribution through aiding developing countries).

For the internal benefit, firstly the high level technology input to the cooperation by Japan can accelerate the innovation process in both United States and China, thereby decrease the $\mathrm{CO}_{2}$ reduction costs. Case study in China [23] suggested that rapid technology improvement could mitigate approximately half of the minus economic influences to achieve a deep reduction target. Hausker et al. [24] also indicated that the most parts of the national target of United States can be realized through deployment of existing technology. At the meanwhile, the deployment of these technologies can activate the industry and keep the competitiveness in Japan. Secondly, the abundant energy resources in United States can contribute to the energy security in Japan and China, which are the top two energy importers in the world. And the high level energy producing technology of the United States such as shale technology can also contribute to low carbon energy supply in the other two countries. Finally, the cheap products from China can significantly contribute to the decease of $\mathrm{CO}_{2}$ reduction costs in United States and Japan. And the high production capacity provides the possibility of deploy the low carbon infrastructure to other developing countries to maintain the industry competitiveness of the three countries.

As to the external effects, three levels of contribution can be expected. On the strategic level, the trilateral cooperation could significantly reduce the energy demand in the three countries by which can release the tension of energy supply market. Therefore, the developing countries in Pacific regions could get cheaper energy to support their economic growth. On the policy level, the most advanced technologies usually couldn't be utilized directly in developing countries due to the limitation of infrastructure and capacity. The trilateral cooperation can generate the more suitable technology and system through R\&D in Japan, industrialization in United States, and commercialization in China just like some practices recently [25]. Finally on the practical level, the capital investments for low carbon infrastructures tend to be larger than traditional ones, thereby limit the deployment in developing countries, even though they can be beneficial during the life cycle. The projection results in this study also illustrated the same problem. The southeastern Asian countries could achieve a benefit of $1.36 \%$ of GDP through fuel saving during 2010-50 compared with the number of $0.1-0.3 \%$ in industrialized countries during the same period. However, the initial additional investment of $0.3 \%$ of GDP compared with the number of $0.05-0.15 \%$ in industrialized countries prevent them to utilize the same technology in the same period [2]. The trilateral cooperation scheme can be expected to solve the problem through a combination of technology and investment.

\section{Conclusions}

United States, Japan and China cover near half of the current global emssions, developed more than half of the global climate technologis, produced most of the global green equipments, thereby are essential player on camboting climate change.

The three countries have a mutually dependent and mutually complementary relationship. Cooperation between the three nations will not only contribute to overcoming the current environment danger but also contribute to energy security and maintaining industrial competitiveness and make international contributions.

Cooperation between the three nations will contribute to achieving energy mixes in harmony with national resource conditions and low carbon growth methods that can be disseminated to developing nations should be established.

Cooperation schemes should be established that go beyond the limits of existing bilateral cooperation with regard to strategy, implementation and deployment.

Based on intergovernmental agreements, infrastructure for the full process flow of technology development, demonstration, industrialization and deployment should be built as the base for cooperation.

\section{Acknowledgements}

This paper is based on a research project launched by the Canon Institute for Global Studies. We'd like to thank the project members, Dr. Hiroshi Ujita, Mr. Masanori Tashimo, Ms Yuriko Aoyanagi, Mr. Kazuaki Matsui, Dr. Toshikazu Shindo, Dr. Kazuhiro Tsuzuki, Dr. Atsushi Kurosawa, Mr. Ken Oyama, Dr. Yasumasa Fujii, and Dr. Ryo Komiyama. We also thank Prof. Taro Matsuno, Mr. Toshihiko Fukui, Mr. Ryozo Hayashi, Mr. Kazumasa Kusaka, and Mr. Akihiro Sawa for their kindly advices on the research. 


\section{REFERENCES}

[1] Duan, F., Ujita, H., and Yuhara, T., Toward a New Climate Regime Establishment (1) Mitigation of Global Warming by Optimum Energy Mixture, 12th IAEE European Energy Conference, September 9-12, 2012, Venice, Italy, 2012.

[2] Duan, F., Yuhara, T., Ujita, H., and Tsuzuki, K., Examination of a Globally Sharable Mid- to Long-Term Vision for a New Climate Regime (in Japanese), Journal of Japan Society of Energy and Resources, Vol. 34, No. 3, 1-11, 2013.

[3] Matsuno T, Maruyama K, Tsutsui J. Stabilization of atmospheric carbon dioxide via zero emissions - An alternative way to a stable global environment. Proceedings of the Japan Academy; Series B 2012;88:368-395.

[4] Kurosawa A, Yagita H, Weisheng Z, Tokimatsu K, Yanagisawa Y. Analysis of carbon emission stabilization targets and adaptation by assessment model. The Energy Journal 1999:20 (Special I), 157-176.

[5] United Nations. Dept. of Economic and Social Affairs. Population Division. World population to 2300. United Nations, 2004.

[6] United Nations. World population prospects, the 2006 revision. Online Database, 2007, http://esa.un.org/unpp.

[7] International Monetary Fund, World Economic Outlook Database, October 2008 Edition. Online Database. http://www.imf.org/external/data.html.

[8] IEA. World Energy Outlook 2009.

[9] USGS, World petroleum assessment 2000, USGS digital data series DDS-60, 2000.

[10] Rogner H-H, An assessment of world hydrocarbon resources, Annu. Rev. Energy Environ. 22, 217-262, 1997.

[11] World Energy Council 2007, 2007 survey of energy

[12] NEDO. Report of Global Warming Control after 2013 (in Japanese), 2004

[13] Yamaji K, Yamamoto H, and Fujino J, Bioenergy (in Japanese), Mion Press, 2000.

[14] IEA. Energy Technology Perspectives 2010.

[15] IEA. World Energy Investment Outlook 2003.

[16] IEA. Solar PV Roadmap targets. 2010.

[17] IEA. Prospects for Hydrogen and Fuel Cells. 2005.

[18] IPCC Special Report. Carbon Dioxide Capture and Storage. 2005.

[19] IEA. Investments and Mitigation Costs, Mitigation costs in the WEO 2009450 Scenario, Potential and costs to reduce fuel consumption in passenger car transport. 2009. http://www.iea.org/weo/investments.asp.

[20] Fulton L, Eads G. IEA/SMP Model Documentation and Reference Case Projection. 2004.

[21] IEA. Technology Roadmap, Electric and plug-in hybrid electric vehicles. 2009.

[22] Dechezlepretre, A., Glachant, M., Iascic, I., Johnstone, N., and Meniere, Y., Invention and Transfer of Climate Change Mitigation Technologies on a Global Scale: A Study Drawing on Patent Data. FEEM Working Paper No. 82. 2009.

[23] Duan, F., Zhang, C., and Zhang, A., Toward a New Climate Regime Establishment (3) Case Study in China, 36th Annual IAEE International Conference, June 16-20, 2013, Daegu, Korea, 2013.

[24] Hausker K., MEEK K, Gasper R., Aden N., and Overter M., Delivering on the U.S. Commitment: A 10-Poing Plan toward a Low-Carbon Future, Working Paper, Washington, DC: World Resources Institute.

[25] National Science Foundation, Science and Engineering Indicators 2012, Alington, VA (NSB-12-01), 2012 